\title{
ANALYSIS AND COMPARISON OF THE ASSET SITUTATION OF THE HUNGARIAN POULTRY AND PORK SECTOR BETWEEN 2005 AND 2015
}

\section{A MAGYAR BAROMFI ÉS SERTÉSÁGAZAT VAGYONI HELYZETÉNEK ELEMZÉSE ÉS ÖSSZEHASOLÍTÁSA 2005 ÉS 2015 KÖZÖTT}

\author{
Andrea Gergely ${ }^{1}$, Mónika Harangi-Rákos ${ }^{2}$, Veronika Fenyves ${ }^{1}$ \\ ${ }^{1}$ Institute of Finance and Accounting, Faculty of Economics, University of Debrecen, Hungary \\ ${ }^{2}$ Institute of Sectoral Economics and Methodology, Faculty of Economics, University of Debrecen,
}

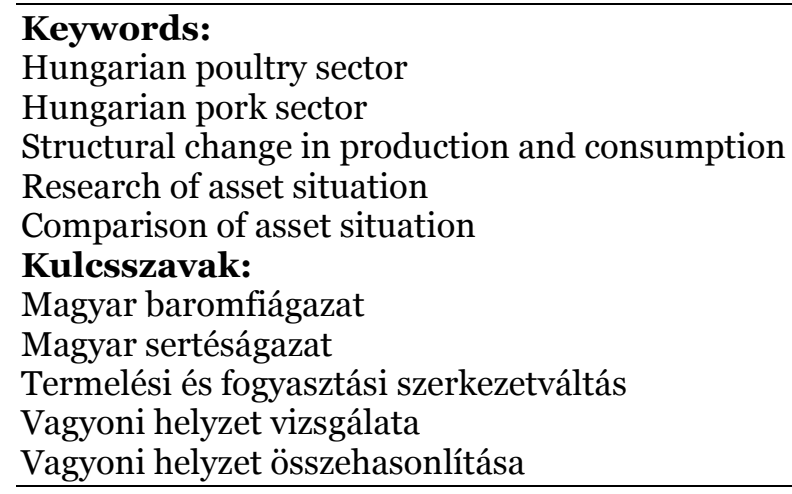

\begin{abstract}
Meat has been playing an important role in the nutrition of humanity from the beginning of time; therefore meat is a fundamental foodstuff. Global population is steadily increasing and people consume more and more foodstuff with high added value including meat and dairy products. In context of meat production and consumption, poultry and pork sector are the major predominant sub-sectors not only nationally, but also internationally. Pork sector had a definite leading role until the end of 1990 . However, this trend has undergone changes and poultry sector is predicted to have this leading role, according to current trends. The aim of our research is to reveal and analize what impacts this structural change have on businesses in these sectors including their asset situations.

\section{Összefoglalás}

Az emberiség táplálkozásában a húsfogyasztás a kezdetektől kiemelkedöen fontos szerepet tölt be, a hús tehát egy alapvetö élelmiszer. A világ népessége folyamatosan növekszik, és az emberek egyre több magas hozzáadott értékü élelmiszert fogyasztanak, mint pl. húst és tejtermékeket. A hústermelés és a húsfogyasztás tekintetében nem csak hazai, hanem nemzetközi szinten is a két legmeghatározóbb szakágazat a baromfi és sertéságazat. Míg a 9o-es évekig egyértelmüen a sertéságazaté volt a vezető szerep, addig ez napjainkra megváltozott, és a jelenlegi trendek szerint a baromfiágazat át fogja venni a vezető szerepet. Kutatásunkkal azt szeretnénk feltárni és megvizsgálni, hogy ennek a szerkezetváltásnak milyen hatása van a két ágazat vállalkozásainak gazdasági, ezen belül vagyoni helyzetére.
\end{abstract}




\section{Introduction}

Man is omnivore and always has been, therefore needs meat and livestock foodstuffs [17]. The structure of food consumption is steadily changing because the consumption of foodstuffs with high added value - primarily meat and dairy products - is ever increasing due to higher household incomes by economic development [16]. In context of meat consumption and production, the most predominant sub-sectors include pork and poultry sector globally, in the EU and in Hungary, as well. Pork production has preceded poultry production to a great extent in the last decades, but poultry sector has started to close this gap in the last 20 years and according to the latest researches and forecasts, the sector is predicted to have the leading role in production, consumption and profitability. We raised the question what impact the structural change had on the economic, that is to say on the asses situation of the two sectors. In order to do so, we carried out our analysis by calculating indicators on datasets of subsectors provided by the Research Institute of Agricultural Economics. The aim of our research was to analyse the trends of the domestic poultry and pork sector in relation to international trends and not only to analyse production and consumption data, but also to use the analysis of specific indicators to evaluate the asset situation of the sub-sectors.

\section{Review of literature}

During the review of the literature, we intended to assess and review the main tendencies of meat industry, including the poultry and the pork sector, both in Hungary and internationally.

Global population is steadily increasing; it was up to 3 billion in 1960, but according to FAO, it is predicted to reach 9 billion by 2026 (Figure 1). Global population more than doubled in 50 years between 1960 and 2010 [11]. As mentioned earlier, therefore, it is not surprising that meat production is growing in parallel with population growth. While beef production was the most dominant in the world in the 1960s, it changed in the 1970s and pork production took the lead. In the 1990s, the production of poultry began to rise sharply and, according to some forecasts and researches, will take the lead. In terms of population data, it is not surprising that the demand for basic foods is also on the rise. The main responsibility of the food industry, both now and in the future, is to be able to supply a growing number of people with high-quality foodstuffs with high nutrient content essential for maintaining health [20]. All the operators in agrobusiness are ahead of serious efforts to solve this responsibility [7] as according to FAO, global population is predicted to increase by an additional $30 \%$ in the next 40 years and food demand is expected to grow by 60\% [6]. According to a study by Marques [13], taking into account that population and income will increase, a global food demand will take place in the upcoming years.

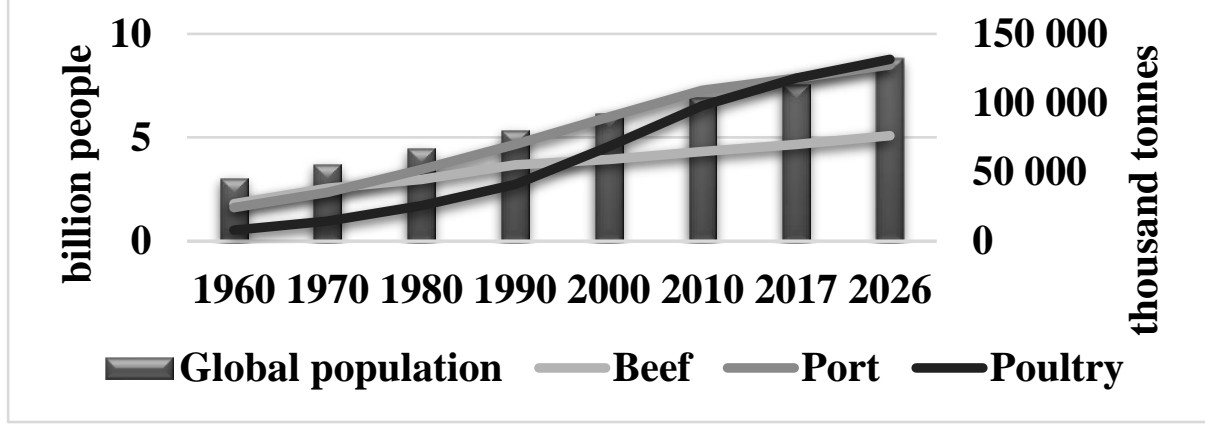

Figure 1 Trend in global population and meat production Source: Own edition, according to OECD-FAO (2017-2026)

The production of poultry has been characterized by rapid development in recent decades, due to industrial production systems [16]. The OECD - FAO estimates that global poultry production amounted to around 118 million tons in 2017, may reach 131 million tons by 2026. The largest poultry producing countries include the USA, China and the EU, with the contribution of two-thirds of the global production. At the end of 2017, the European 
Commission predicted that EU poultry production would continue to grow until 2030 and that production of the community of 2018 is expected to be up to 15 million tons, which means a slight increase compared to the previous year [2]. Poultry production in the EU-27 increased by $5 \%$ between 2015 and 2016, reached 14 million tons by 2017, in part due to low feed prices. Chicken meat accounts for more than two-thirds of poultry production in the EU-27. Hungarian poultry production also shows quite large fluctuations during the period under review. According to the latest available data by the Hungarian Central Statistical Office, in 2015, Hungary produced 490 thousand tons of poultry, of which nearly 230 thousand tons were exported. On the other hand, Hungarian imports are slight. Since 1970, per capita consumption of poultry has doubled, reaching nearly $30 \mathrm{~kg} /$ capita in 2015 . One of the main strengths of the Hungarian meat industry is export production, which is especially true for poultry. This is backed by the fact that, between 2010 and 2015, our poultry export increased by more than 70,000 tons, thus reducing the decline of previous years. The vast majority of domestic poultry exports are covered by chicken and turkey [10].

Pork production in the EU was increased by 1.3\% from 2015 to 2016, exceeding 23 million tons, mainly due to exports to China. Of the countries, pork consumption per capita is the highest, with $61 \mathrm{~kg}$ in Hong Kong. This is followed by four EU member states; Austria, Germany, Poland and Spain. In these countries, annual consumption exceeds $50 \mathrm{~kg}$. Annual consumption in the EU is $40 \mathrm{~kg}$ per capita. In Hungary, this value is about $10 \mathrm{~kg}$ higher than the global average, whereas in Hungary $27 \mathrm{~kg}$ of pork is consumed per capita, while on average only $16 \mathrm{~kg}$ of pork is consumed annually in the world [12]. According to the European Commission, pork export of the EU is extremely high compared to its import. In 2017, the volume of export exceeded 2.5 million tons, compared to the import volume of 13,000 tons. As a conclusion, the EU is a net exporter both of poultry and pork. Pork consumption per capita was on an average of $31 \mathrm{~kg}$ in 2017. The EU Commission predicts that pork exports of the community will decline from 2018 until 2022, followed by a growing trend until 2030.

\section{Material and methodology}

For a deeper and more accurate analysis of the two sectors, we needed special data for this purpose. These data were provided by a member of the Research Institute of Agricultural Economics, thus allowing us to prepare our publication and carry out an analysis that has not been carried out before. On the basis of the data already available, the economic analysis of the two sectors was carried out, because the purpose and task of the economic analysis are to process the data available, and to use this information to increase the efficiency and effectiveness of farming [4].

Database provided by the Research Institute of Agricultural Economics was used to our study. The database covers data on the various balance sheets and profit and loss accounts of businesses in the Hungarian poultry and pork sector from 2005 to 2015. Our study covers 11 years. Data for 2015 were available not only in aggregate, but also in three size categories based on standard production value in both sectors.

The vast majority of the data in the database are in 1000 HUF/ livestock. Some of the key figures in the balance sheet and profit and loss account were available in other units, e.g. 1000 HUF / plant, and 1000 HUF / 1000 EUR standard production value. Basically our calculations were carried out using data in $1000 \mathrm{HUF} /$ livestock unit.

In the course of our research, we delved into whether the situation of the Hungarian poultry and pork sector develops similarly to the international trends, and which sector's asset situation is more favourable.

\section{Results}

\subsection{Analysis of the profit/loss after taxation, equity, total assets and balance sheet earnings of the sectors}

In order to start our research, I first analysed the trend of the most important balance sheet values of the two sectors, as illustrated in Figure 2. 
Between 2005 and 2015, the total asset value of the pork sector shows a clear steady growth, as by the end of the period this value has more than doubled. The total asset value of businesses in the poultry sector was almost three times higher at the beginning of the same period, but in this case, a fluctuation of approximately $10-20 \%$ is observed. Based on the trend of the values of equity, it can be concluded that the values of the poultry sector show the same fluctuation as observed in the examination of the values of total assets, which means that the fluctuation of the values of total assets derives from the change in the values of equity. Of course, we can only draw a firm conclusion after observing the trends of the values of liabilities. Although the value of equity in the pork sector increased slowly between 2005 and 2012, it continued to grow steadily, followed by a steady decline in the following years. As the total value of assets in the sector increased steadily, despite a decrease in equity, this is clearly due to an increase in liabilities.
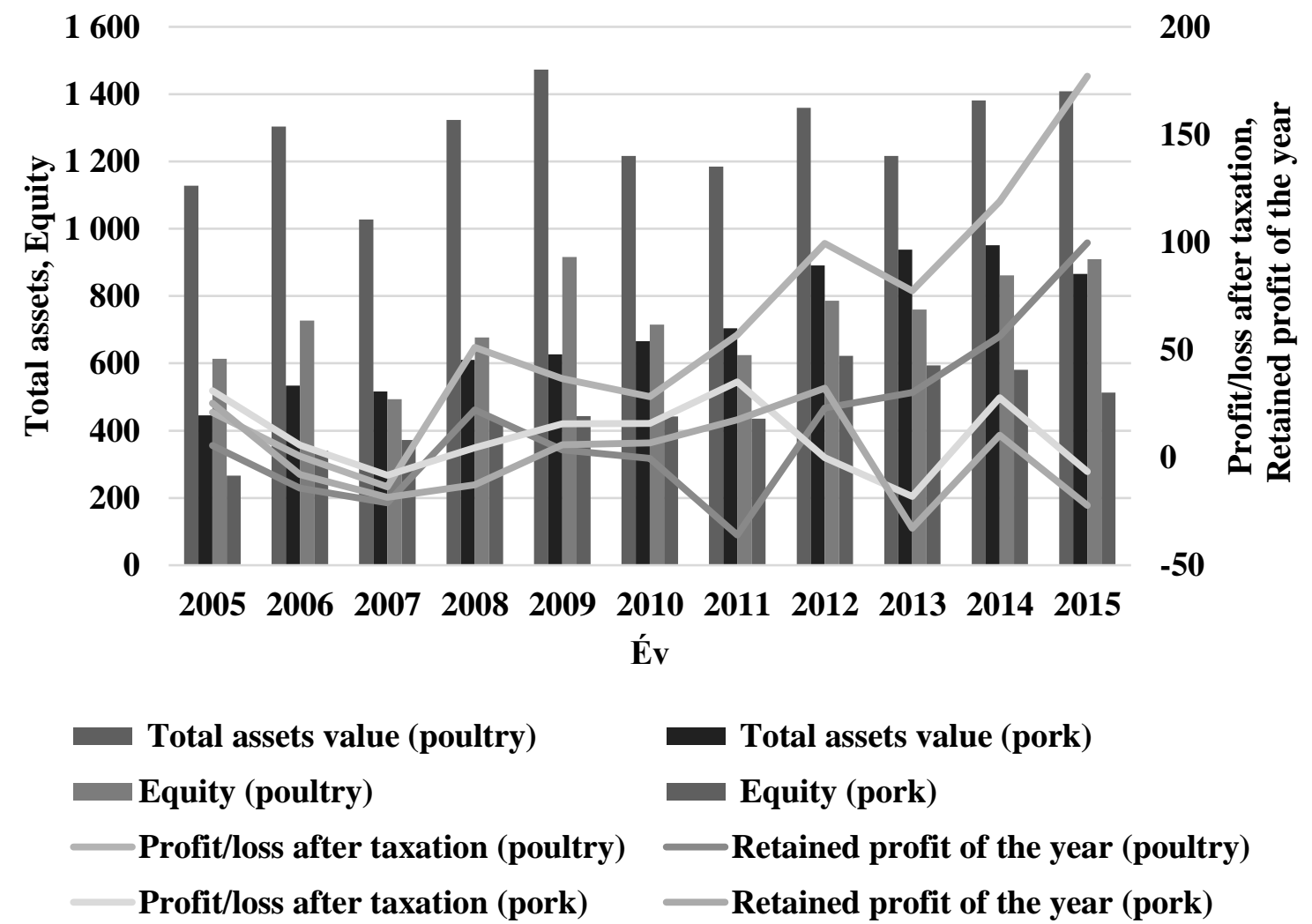

Figure 2 Trends in balance sheet total, equity, profit/loss after taxation and balance sheet earnings of businesses in the Hungarian poultry and pork sector between 2005 and 2015

Based on the values of the profit/loss after taxation and balance sheet earnings, it can be clearly concluded that there is an even higher growth in the poultry sector. Of course, the effects of the financial crisis in 2008 are well reflected in Figure 2, as the profit/loss after taxation and balance sheet earnings of the poultry sector plunged, in addition, show negative values in several cases. However, during the years following the crisis, the same balance sheet data for the pork sector show a slow, but steady growth. After 2012, the poultry sector has clearly taken the lead in this respect and achieved outstanding results compared to the initial values.

As data for 2015 were also available for breakdown by size categories, data for this year were also analysed in this respect (Figure 3). Compared to the previous year, the total value of assets and equity of businesses in poultry breeding continued to increase in 2015, while the same values of businesses in pork breeding began to decline. The value of profit/loss after taxation and balance sheet earnings of the pork sector fell sharply in 2015 compared to the previous year, while the same values in the poultry sector show a remarkable increase. Data for both sectors are shown in three size categories in Figure 3. 


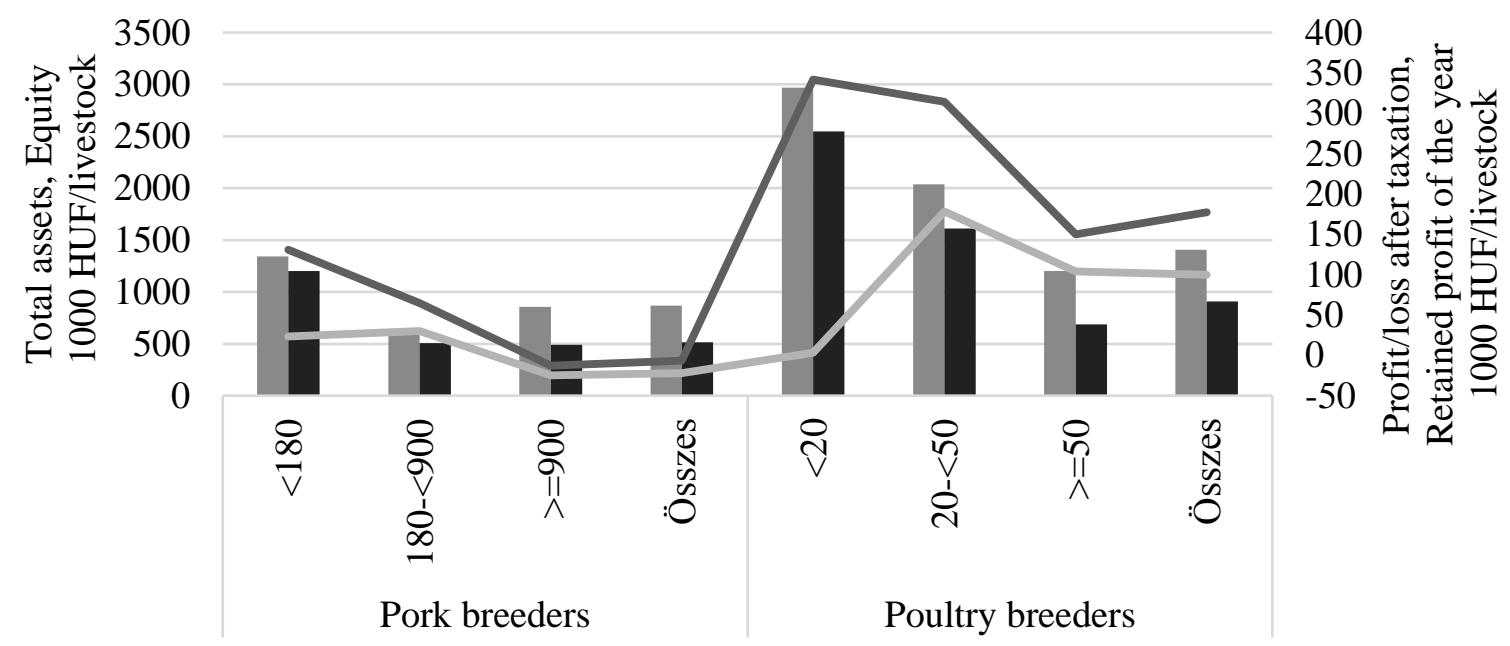

Size categories by sectors

Figure 3 Analysis of trends in balance sheet total, equity, profit/loss after taxation and balance sheet earnings of businesses in different sizes in the Hungarian poultry and pork sector in 2015 values.

For both sectors, small-sized companies perform the best in context of analysing these

\subsection{Study of balance sheet data and the analysis of its internal structure}

The analysis of the asset situation is worth starting with an overview of the assets and liabilities in the balance sheet, as the assets provide a more accurate picture of the asset situation, flexibility and core activity, while liabilities inform about capital strength and foreign capital dependency [5]. The two sides of the balance sheet can not only be analysed separately, but we can analyse the correlations between the two sides due to the horizontal indicators [14] [15].

In the case of the asset analysis, the rate of fixed and current assets is primarily compared with the balance sheet total (Table 1). Of the fixed assets, the database contains only the value of the real estates; therefore in this case, we compared the value of the real estates to the value of total assets. Although we could reduce the rate of fixed assets by the rate of current assets, however, the value and rate of Accrued income and Deferred charges is unknown, so we could only use the existing data. The rates of both sectors show some fluctuations during the period under review, ranging from $30 \%$ to $40 \%$. There is no acceptable minimum or maximum value in the literature for the rate of fixed assets, as the value of this indicator is highly dependent on industry specificities [19]. If the value of fixed assets is high, it indicates that the operation of the business is stable and enduring, but it should be mentioned that fixed assets are profitable and have illiquid nature. If there is a high rate of fixed assets, the rate of fixed costs will probably be higher due to the high overhead and machine costs. If there is a high rate of fixed assets, it will allow fewer chances for change in the company profile. In both sectors, buildings and structures have high rates in real estate.

It is true for both sectors that the rate of their current assets is slightly higher than the rate of their fixed assets, as the values of this indicator range from 35\% to 45\%. Stocks are definitely dominant in current assets, as under the current Accounting Act, animals for breeding and fattening and other livestock are recorded in stocks. 
Table 1 Analysis of trends in balance sheet groups of businesses in Hungarian poultry and pork sector between 2005 and 2014

\begin{tabular}{|c|c|c|c|c|c|c|c|c|c|c|}
\hline Poultry & 2005 & 2006 & 2007 & 2008 & 2009 & 2010 & 2011 & 2012 & 2013 & 2014 \\
\hline $\begin{array}{l}\text { Rate of real } \\
\text { estates }\end{array}$ & $33 \%$ & $37 \%$ & $44 \%$ & $43 \%$ & $36 \%$ & $42 \%$ & $40 \%$ & $41 \%$ & $45 \%$ & $41 \%$ \\
\hline $\begin{array}{l}\text { Rate of } \\
\text { current } \\
\text { assets }\end{array}$ & $38 \%$ & $36 \%$ & $36 \%$ & $41 \%$ & $47 \%$ & $36 \%$ & $43 \%$ & $43 \%$ & $35 \%$ & $38 \%$ \\
\hline $\begin{array}{l}\text { Rate of } \\
\text { stocks }\end{array}$ & $34 \%$ & $34 \%$ & $42 \%$ & $36 \%$ & $29 \%$ & $34 \%$ & $31 \%$ & $31 \%$ & $45 \%$ & $37 \%$ \\
\hline $\begin{array}{l}\text { Equity } \\
\text { strength }\end{array}$ & $54 \%$ & $56 \%$ & $48 \%$ & $51 \%$ & $62 \%$ & $59 \%$ & $53 \%$ & $58 \%$ & $62 \%$ & $62 \%$ \\
\hline $\begin{array}{l}\text { Rate of } \\
\text { liabilities }\end{array}$ & $44 \%$ & $44 \%$ & $51 \%$ & $48 \%$ & $37 \%$ & $39 \%$ & $46 \%$ & $41 \%$ & $37 \%$ & $37 \%$ \\
\hline $\begin{array}{l}\text { Rate of long- } \\
\text { term } \\
\text { liabilities }\end{array}$ & $35 \%$ & $26 \%$ & $25 \%$ & $25 \%$ & $17 \%$ & $27 \%$ & $16 \%$ & $9 \%$ & $16 \%$ & $16 \%$ \\
\hline $\begin{array}{l}\text { Rate of } \\
\text { short-term } \\
\text { liabilities }\end{array}$ & $61 \%$ & $67 \%$ & $64 \%$ & $54 \%$ & $70 \%$ & $65 \%$ & $75 \%$ & $83 \%$ & $73 \%$ & $70 \%$ \\
\hline $\begin{array}{l}\text { Change in } \\
\text { equity }\end{array}$ & $1 \%$ & $-2 \%$ & $-4 \%$ & $3 \%$ & O\% & O\% & $-6 \%$ & $3 \%$ & $4 \%$ & $7 \%$ \\
\hline $\begin{array}{l}\text { Equity } \\
\text { pressure }\end{array}$ & 0,80 & 0,78 & 1,06 & 0,94 & 0,60 & 0,67 & 0,88 & 0,71 & 0,59 & 0,59 \\
\hline $\begin{array}{l}\text { Net working } \\
\text { capital }\end{array}$ & 124 & 91 & 33 & 197 & 306 & 133 & 98 & 117 & 100 & 174 \\
\hline Pork & 2005 & 2006 & 2007 & 2008 & 2009 & 2010 & 2011 & 2012 & 2013 & 2014 \\
\hline $\begin{array}{l}\text { Rate of real } \\
\text { estates }\end{array}$ & $37 \%$ & $38 \%$ & $38 \%$ & $40 \%$ & $39 \%$ & $38 \%$ & $34 \%$ & $37 \%$ & $40 \%$ & $32 \%$ \\
\hline $\begin{array}{l}\text { Rate of } \\
\text { current } \\
\text { assets }\end{array}$ & $47 \%$ & $45 \%$ & $46 \%$ & $43 \%$ & $41 \%$ & $38 \%$ & $45 \%$ & $41 \%$ & $37 \%$ & $42 \%$ \\
\hline $\begin{array}{l}\text { Rate of } \\
\text { stocks }\end{array}$ & $54 \%$ & $41 \%$ & $52 \%$ & $55 \%$ & $55 \%$ & $55 \%$ & $53 \%$ & $54 \%$ & $52 \%$ & $60 \%$ \\
\hline $\begin{array}{l}\text { Equity } \\
\text { strength }\end{array}$ & $60 \%$ & $64 \%$ & $72 \%$ & $71 \%$ & $71 \%$ & $66 \%$ & $62 \%$ & $70 \%$ & $63 \%$ & $61 \%$ \\
\hline $\begin{array}{l}\text { Rate of } \\
\text { liabilities }\end{array}$ & $40 \%$ & $36 \%$ & $27 \%$ & $28 \%$ & $27 \%$ & $31 \%$ & $35 \%$ & $28 \%$ & $31 \%$ & $38 \%$ \\
\hline $\begin{array}{l}\text { Rate of long- } \\
\text { term } \\
\text { liabilities }\end{array}$ & $48 \%$ & $24 \%$ & $18 \%$ & $14 \%$ & $13 \%$ & $19 \%$ & $22 \%$ & $20 \%$ & $47 \%$ & $21 \%$ \\
\hline $\begin{array}{l}\text { Rate of } \\
\text { short-term } \\
\text { liabilities }\end{array}$ & $48 \%$ & $69 \%$ & $67 \%$ & $71 \%$ & $70 \%$ & $70 \%$ & $72 \%$ & $66 \%$ & $41 \%$ & $65 \%$ \\
\hline $\begin{array}{l}\text { Change in } \\
\text { equity }\end{array}$ & $9 \%$ & $-2 \%$ & $-5 \%$ & $-3 \%$ & $1 \%$ & $2 \%$ & $4 \%$ & $5 \%$ & $-6 \%$ & $2 \%$ \\
\hline $\begin{array}{l}\text { Equity } \\
\text { pressure }\end{array}$ & 0,67 & 0,56 & 0,38 & 0,39 & 0,38 & 0,47 & 0,57 & 0,40 & 0,50 & 0,62 \\
\hline
\end{tabular}




\begin{tabular}{|l|l|l|l|l|l|l|l|l|l|l|}
\hline $\begin{array}{l}\text { Net working } \\
\text { capital }\end{array}$ & 123 & 111 & 142 & 138 & 137 & 106 & 137 & 199 & 228 & 162 \\
\hline
\end{tabular}

The equity strength indicator expresses the rate of equity to balance sheet total, so we turned to the analysis of liabilities in the balance sheet. Equity strength indicators of the sectors are considered to be particularly satisfying, as we cannot identify critical values on the assets side due to industry specificities, while regarding liabilities, literature has values. In the case of the equity rate, this value is around $30 \%$, according to the literature, if the value of the indicator is $30 \%$ or less, it means critical asset situation, a company with equity strength of 55$60 \%$ is considered strong [9]. With the exception of some fluctuations, equity strength indicators of the two sectors show an upward trend, exceeding $60 \%$ in several years, which is particularly positive.

Analysing the rate of liabilities in a complex analysis is crucial. Similarly to the equity values, the rate of liabilities of the two sectors developed very favourably during the period analysed, as both sectors managed to reduce the rate of their liabilities. It is also true for both sectors that short-term liabilities dominate within liabilities. Although it does not appear in the calculated values of Table 1, it can be seen from the database that $50 \%$ of long-term liabilities are made up of investment and development credits, which also represents a positive picture of the sector. Half of the short-term liabilities are due to supplier liabilities.

When analysing the liabilities in the balance sheet, I noticed that the sectors do not have provisions, so I did not include this rate in Table 1, but I consider it important to mention.

The indicator of change in equity for both sectors is below $10 \%$ in all years analysed, and in many cases negative. However, the indicator is increasing slightly towards the end of the period in the poultry sector, but decreasing values are observed in the pork sector. The value of the indicator is considered satisfying if it exceeds the value of the Central Bank base rates, therefore low indicator values do not necessarily pose a problem.

In the case of equity pressure, high values are acceptable if they are generated by high investment costs. As I mentioned earlier in the analysis of liabilities, investment and development credits were high, so in this case the trend of these values is also satisfying.

Working capital is essential for determining the short-term asset situation of businesses. Net working capital can be defined as the difference between the business' current assets and its short-term liabilities, i.e. the part of current assets that is not tied up with short-term liabilities. Net working capital can also be interpreted as the netting of working capital. It can be also concluded that the net working capital is the part of current assets that is financed with long-term financial assets or equity, i.e. long-term liabilities. The higher the value of net working capital is, the more flexible the financing policy of the company is. If this value is negative, some of the fixed assets will be financed by short-term liabilities, this is called aggressive financing policy, but it is dangerous enough because fixed assets must be used permanently to operate and short-term liabilities must be used to maintain operability. The net working capital values of the two sectors are not very high, but they do not have any negative value during the years analysed, therefore it does not mean aggressive financing policy.

Data for 2015 were analysed not only on the total value, but also on the basis of the size category breakdown, I analysed the previously examined ratios. For the sake of clarity, we summarized the trend of the indicators in Table 2.

The rate of real estates increased significantly in neither sector compared to 2014. On the other hand, according to the size category breakdown, the rate of real estates in both sectors is the largest in businesses in the smallest size category.

In 2015, there was no significant change in current assets compared to the previous year. The rate of current assets in both sectors is the highest for mid-size companies.

The rate of stocks for both pork and poultry breeders is the highest for those of the largest size category, which is crucial to mention, as the value of stocks is significantly higher in comparison to smaller categories. This is presumably due to the fact that larger businesses can keep a larger number of animals, and according to the Accounting Act [1], animals for breeding and fattening and other livestock are listed in stocks, so the high ratio shown here is due to this fact. 
Table 2 Analysis of data in balance sheets of Hungarian poultry and pork breeders in 2015

\begin{tabular}{|l|l|l|l|l|l|l|l|l|}
\hline \multirow{2}{*}{2015} & \multicolumn{5}{|c|}{ Pork breeders } & \multicolumn{4}{c|}{ Poultry breeders } \\
\cline { 2 - 9 } & \multicolumn{1}{|c|}{$<180$} & $180-<900$ & $>=900$ & Total & $<20$ & $20-<50$ & $>=50$ & Total \\
\hline $\begin{array}{l}\text { Rate of real } \\
\text { estates }\end{array}$ & $44 \%$ & $36 \%$ & $32 \%$ & $32 \%$ & $50 \%$ & $38 \%$ & $37 \%$ & $40 \%$ \\
\hline $\begin{array}{l}\text { Rate of } \\
\text { current } \\
\text { assets }\end{array}$ & $47 \%$ & $51 \%$ & $44 \%$ & $45 \%$ & $32 \%$ & $41 \%$ & $40 \%$ & $39 \%$ \\
\hline $\begin{array}{l}\text { Rate of } \\
\text { stocks }\end{array}$ & $25 \%$ & $34 \%$ & $61 \%$ & $59 \%$ & $25 \%$ & $24 \%$ & $48 \%$ & $42 \%$ \\
\hline $\begin{array}{l}\text { Equity } \\
\text { strength }\end{array}$ & $89 \%$ & $82 \%$ & $57 \%$ & $59 \%$ & $86 \%$ & $79 \%$ & $57 \%$ & $65 \%$ \\
\hline $\begin{array}{l}\text { Rate of } \\
\text { liabilities }\end{array}$ & $11 \%$ & $18 \%$ & $42 \%$ & $40 \%$ & $14 \%$ & $21 \%$ & $41 \%$ & $34 \%$ \\
\hline $\begin{array}{l}\text { Rate of long- } \\
\text { term } \\
\text { liabilities }\end{array}$ & $14 \%$ & $57 \%$ & $12 \%$ & $13 \%$ & $5 \%$ & $33 \%$ & $22 \%$ & $21 \%$ \\
\hline $\begin{array}{l}\text { Rate of } \\
\text { short-term } \\
\text { liabilities }\end{array}$ & $52 \%$ & $36 \%$ & $80 \%$ & $80 \%$ & $67 \%$ & $52 \%$ & $64 \%$ & $64 \%$ \\
\hline $\begin{array}{l}\text { Change in } \\
\text { equity }\end{array}$ & $2 \%$ & $6 \%$ & $-5 \%$ & $-4 \%$ & $0 \%$ & $11 \%$ & $15 \%$ & $11 \%$ \\
\hline $\begin{array}{l}\text { Equity } \\
\text { pressure }\end{array}$ & $12 \%$ & $22 \%$ & $73 \%$ & $67 \%$ & $17 \%$ & $26 \%$ & $72 \%$ & $53 \%$ \\
\hline $\begin{array}{l}\text { Net working } \\
\text { capital }\end{array}$ & 557,44 & 274,86 & 91,86 & 110,80 & 669,80 & 616,83 & 166,44 & 238,34 \\
\hline
\end{tabular}

It may be surprising that equity strength of the smallest group in both sectors is extremely high, close to $90 \%$. As a result, their rate of liabilities is very low, unlike the largest businesses. The excessively high equity strength values are not necessarily favourable in all cases, as it can lead to excess liquidity, which is also unfavourable.

Based on the structure of liabilities, short-term liabilities dominate in both sectors, while in the case of pork farms; the share of short-term liabilities is highest in companies of the largest size category, whereas in the case of poultry keepers this proportion is the lowest for companies with the smallest size.

In 2015, the rate of change in equity for pork breeders was unfavourable compared to the previous year, with the medium-sized companies in this sector performing best. This year, poultry keepers were able to grow compared to 2014, with large-scale companies performing best in terms of equity.

In the case of the equity pressure indicator, businesses of the largest group in both sectors performed best, reaching high values above $70 \%$.

According to the calculation of net working capital, companies of the smallest size did the best, as their value is the highest in this case. However, it is also important to mention here that high values can lead to excess liquidity, which can lead to deterioration in profitability.

Based on these studies, it is not yet possible to draw far-reaching conclusions, so further analysis of the companies in the two sectors is needed to get a more accurate picture [8]. On 
the other hand, it appears that the asset situation of poultry breeders shows an improving trend between 2005 and 2015, as opposed to pork breeders who show a slow pace of decline.

\section{Summary}

The main purpose of our publication was to study and analyse the financial situation of the Hungarian poultry and pork sector between 2005 and 2015. The actuality of our choice of topic is confirmed by the change in the consumption structure. The aim of our research was to prepare a detailed sector-level analysis, which can be considered as a niche as the number of analyses describing the overall economic situation of the two sectors is low.

During the review of literature we presented the international and domestic situation of the poultry and the pork sector and the trends of production and consumption. We tried to present the similarities and contradictions between the two sectors thoroughly.

We used the database provided by the Research Institute of Agricultural Economics as the basis of our research and analysis. The database contains data on various balance sheets and profit and loss accounts of the Hungarian poultry and pork sector between 2005 and 2015. Data for 2015 were available in three size categories based on Standard Production Value.

In the course of the research, we examined the data of the available financial statements using indicators including the trend of the asset and equity structure.

Based on our results, it can be concluded that the trend of the economic situation of the two sectors shows the same picture with international production and consumption trends.

\section{Bibliographical References}

[1] 200o. évi C törvény a számvitelről. https://net.jogtar.hu/jogszabaly?docid=Aoooo1oo.TV [Accessed: 23Oct-2018]

[2] Agrárgazdasági Kutató Intézet (2017): Agrárpiaci jelentés. Baromfi. 12 (22) pp. 1-20.

[3] Agrárgazdasági Kutató Intézet (2017): A főbb mezőgazdasági ágazatok költség- és jövedelemhelyzete 20132015., pp. 38-44.

[4] Bán, E. - Kresalek, P. - Pucsek, J. (2017): A vállalati gazdálkodás elemzése. Perfekt Gazdasági Tanácsadó, Oktató és Kiadó Zrt., Budapest

[5] Bíró, T. - Kresalek, P. - Pucsek, J. - Sztanó, I. (2016): A vállalkozások tevékenységének komplex elemzése. Budapest, Perfekt Gazdasági Tanácsadó, Oktató és Kiadó Zrt., pp. 11-53.

[6] FAO (2018): http://www.fao.org/faostat/en/\#data/OA [Accessed: 10-May-2018]

[7] Horn, P. - Sütő, Z. (2014): Poultry production of the world and the competitiveness of its production. In: Acta Agraria Kaposváriensis. 18 (1) pp. 14-29.

[8] Karai, É. - Laáb, Á. - Szívós, L. - Rózsa, I. (2015): Pénzügyi számviteli elemzések. Budapest. pp. 1-83.

[9] Kardos, B. - Sztanó, I. - Veress, A. (2007): A vezetői számvitel alapjai. Budapest. Saldo Kiadó Zrt., pp. 245278.

[10] KSH (2018): 4.1.2.1.7. Baromfihús mérlegtábla.

http://www.ksh.hu/docs/hun/xstadat/xstadat_hosszu/elmo7.html [Accessed: 12-Jun-2018]

[11] Kozák, J. (2015): A világ hústermelésének, kereskedelmének és fogyasztásának tendenciái. In: Gazdálkodás, 59 (1) pp. 20-34.

[12] Magyar Állattenyésztők Szövetsége (2016): Sertéságazat helye és szerepe. Dr. Wagenhoffer Zsombor előadása. http://vitafort.hu/uploads/sertesagazat_helye_es_szerepe_wagenhoffer_zsombor.pdf [Accessed: 22-May2018]

[13] Marques, A. C. - Fiunhas, J. A. - Pais, D. F. (2018): Economic growth, sustainable development and food consumption. Evidence across different income groups of countries. In: Journal of Cleaner Production, Vol. 196. pp. 245-258.

[14] Musinszki, Z. (2013): Mit mutat a mérleg? A hányadoselemzés alapjai és buktatói I. In: Controller Info, 1 (12) pp. 20-26.

[15] Musinszki, Z. (2014): Mit mutat a mérleg? A hányadoselemzés alapjai és buktatói II. In: Controller Info, 2 (1) pp. 42-53.

[16] Popp, J. (2013): A baromfi ágazat globális helyzete és kilátásai. (I.). Baromfiágazat. 13 (4) pp. 4-11.

[17] Popp, J. - Oláh, J. - Szenderák, J. - Harangi-Rákos, M. (2017): A marhahús előállítás nemzetközi és hazai piaci kilátásai. In: Állattenyésztés és Takarmányozás. 66 (4) pp. 276-299.

[18] Szücs, I. - Vida, V. - Szakály, Z. (2017): Sertéshús fogyasztási szokások. 2017-es előadás, Budapest. pp. 1-32.

[19] Takács, A. (2015): Vállalatértékelés - Magyar számviteli környezetben. Budapest, Perfekt Zrt., pp. 11-24.

[20] Zsótér, B. - Túri, I. (2017): Economical calculations related to a smoking technology investment of a pork processing plant. In Annals of faculty of Engineering Hunedoara - International Journal of Engineering, 15 (4) pp. 57-61. 
